\title{
A solution in iron solution?
}

\section{Washington}

A proposal that the greenhouse effect could be inexpensively mitigated by artificially stimulating massive blooms of algae in the Antarctic Ocean has outraged environmentalists and drawn attention from researchers, the press and even the White House. The proposal, by John Martin of the Moss Landing Marine Laboratory was first published in these pages (see Nature 345, 114 \& 156; 10 May 1990), but when the Washington Post, in a front-page story, independently picked up the idea last week, Martin's office was besieged by calls.

"I'm astounded", Martin says of the reaction. However, the National Research Council took his idea seriously at a workshop convened last December at the suggestion of Adam Heller of the University of Texas. During the two-day meeting, participants even suggested a $\$ 50$ to $\$ 150$ million trial experiment.

The logic of Martin's idea comes from evidence that the growth of phytoplankton in the Antarctic Ocean is restricted by a shortage of iron. Other nutrients abound, but in the southern regions far from dry land and wind-borne dust, Martin finds that levels of dissolved iron are among the lowest in the world. Because phytoplankton fix carbon dioxide during photosythesis, adding about 300,000 tonnes of iron to the ocean could stimulate algal growth sufficiently to soak up more than 2,000 million tonnes of carbon - roughly a third of the amount put in the atmosphere each year by deforestation and fossil-fuel burning.

For those who worry that enforcing drastic cuts in $\mathrm{CO}_{2}$ emissions would return the developed world to the pre-industrial age, man-made algal blooms sound like an attractive way out. But Martin's solution to climate change is attracting plenty of criticism.

Biologists, noting the deadly effects of algal blooms in the Adriatic, are concerned about the impact on the food chain. Oceanographers and atmospheric scientists say that the phytoplankton may simply release most of the carbon back into the atmosphere when they die, rather than sinking to the ocean floor. And some policy analysts worry that if every industry could fill a tanker with iron to atone for its carbon sins, few would take expensive and restrictive measures to keep emissions down. "We're not iron-poor, we're pollution-rich", says Daniel Becker of the Sierra Club.

Environmentalists look poorly on 'megabiology' - global tampering with the biosphere. Atmospheric scientist Michael Oppenheimer of the Environmental Defense Fund is reminded of earlier suggestions to combat global warming with huge mirrors in space (to reflect away sunlight) or to regenerate stratospheric ozone with orbiting lasers. "The whole thing smacks of the megaproject-itis that infects large areas of the scientific community when it comes to environmental problems", he says. "If there is one thing we've learned in the last twenty years, it's that there are always unintended implications of what we do to the environment."

Reaction from the scientific community has been more encouraging, although serious questions remain unanswered. Among the more glaring gaps are the limited understanding of $\mathrm{CO}_{2}$ exchange between the atmosphere and the ocean and the movement of carbon from the surface to greater depths. Although Martin says iron appears to be by far the most important limiting agent for algal growth in polar water, his is the only major study on the subject. When saturated with iron, large-scale phytoplankton blooms may still be limited by some other unexpected nutrient or condition. "Biological systems are famous for not doing what they're supposed to do", says David Caron of the Woods Hole Oceanographic Institution.

Others suggest that Martin may be observing an increase in the rate of algal growth, rather than its overall volume.
But Martin says laboratory tests indicate that the addition of iron can increase total phytoplankton biomass tenfold. And even if it is only the rate of growth that is accelerated, short Antarctic summers put a premium on speedy development. During the few months when polar conditions are right, the fastest-growing algae are likely to produce the most biomass and soak up the most $\mathrm{CO}_{2}$, he says.

Despite the doubts, the scientific consensus appears in favour of trying out Martin's theory in the field, on a modest scale. Martin suggests putting a tonne of iron in an area $10-100 \mathrm{~km}$ square in the Gulf of Alaska, which is relatively easy to get to and has phytoplankton conditions similar to the Antarctic. An experiment of that sort would cost between $\$ 10$ and $\$ 50$ million, he estimates.

Such a test could answer the most immediate questions about the impact on other plants and animals in the region of the algal blooms. The NRC is expected to convene another workshop on the subject in August or September. NRC officials say a full-scale, peer-reviewed report could be released in late 1991. Along with the National Science Foundation and the Electric Power Research Institute, which funded part of the NRC workshop, the US Environmental Protection Agency has expressed interest in funding further research in the area as part of the $\$ 1,000$ million US climate change programme.

G. Christopher Anderson FRENCH UNIVERSITY REFORMS

\section{Emergency investment plan under way}

Paris

A CABINET meeting on 23 May approved French education minister Lionel Jospin's plans to invest an extra FF16,000 million (\$2,900 million) over five years in order to relieve severe and growing overcrowding in France's universities (see Nature 342, 723; 1989).

The move follows a promise by President François Mitterrand earlier this month to build 1.5 million square metres of new university facilities. Mitterrand said last week that the new plans are "unprecedented", but added that so is the demand Student applications for university places were up by about 80,000 last year and the extra demand is expected to be even greater this autumn. Early last year, Jospin declared that 80 per cent of pupils should leave school with a university entrance certificate (baccalauréat).

University buildings in the Paris region are already severely overcrowded and several are showing signs that they were built in a hurry to meet a similar expansion in the early 1970s. Five new universities are planned for suburbs and dormitory towns around Paris, another for Pas-deCalais on the Channel coast and possibly two others in the provinces.

There is also a critical need to extend existing facilities, especially libraries and student accommodation. But the government's new package is unlikely to be sufficient to cover all the costs. So Jospin is relying upon regional and local governments to share some of the burden. This is may not be easy, especially since the government is unwilling to let local authorities have much of a say in higher education policy.

The plans have received a lukewarm reception from university teachers' unions. The new funds are felt undeniably to be welcome but are inadequate, they say. Also they fear that local governments will not pick up the extra bill because they will be reluctant to run the electoral risk of having to pass it on to the taxpayer.

Jospin's plans are still not out of the woods. The education budget has to be approved by parliament in the autumn, although the proposals have received guarded opposition support. A series of hearings are also planned this summer to negotiate the university reforms in each region and administrative department of the country.
Peter Coles 